\title{
Nasogastrisk sonde på ville veier
}
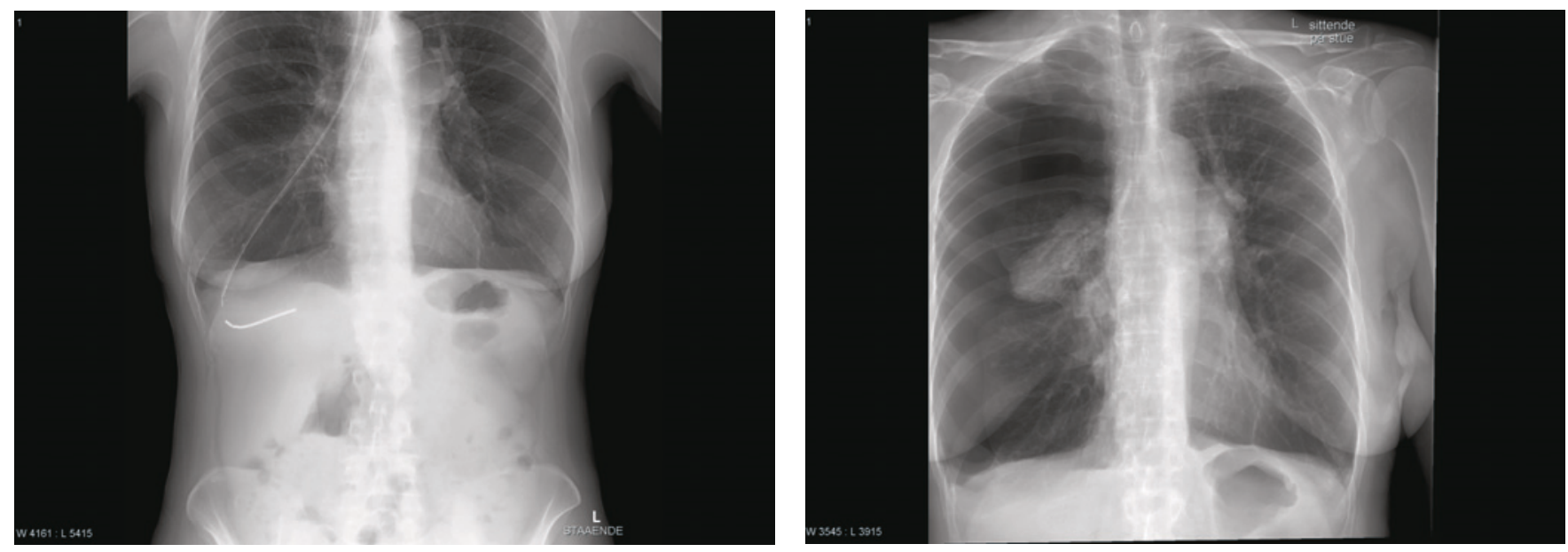

En kvinne i 60-årene var innlagt med svelgevansker og ernæringsproblemer. Hun var fra tidligere diagnostisert med supraglottisk plateepitelcancer og behandlet med utvidet strålefelt mot halsen og med cytostatika. Ved denne innleggelsen fikk hun lagt ned en tynn nasogastrisk sonde. Sonden hadde ytre diameter 1,95 mm og en stålmandreng. Den lot seg tilsynelatende føre ned ukomplisert. Ved instillasjon av $10 \mathrm{ml}$ luft hørtes ikke bobler som normalt over magesekken. Røntgen av nedre thorax og øvre abdomen viste at sonden hadde fulgt bronkialtreet langt ut $\mathrm{i}$ høyre lunge (bilde til venstre). Sonden ble fjernet, men kort tid etter fikk kvinnen store pusteproblemer og stansalarmen måtte aktiveres. Røntgen thorax viste en stor høyresidig pneumothorax (bilde til høyre). Den ble vellykket behandlet med kirurgisk anlagt pleuradren.

Pasienter med gjennomgått cancer og strålebehandling i øre-nese-hals-området har ofte store ernærings- og svelgevansker som gjør det nødvendig å legge ned en nasogastrisk sonde. Samtidig er ofte anatomiske forhold endret og vanlige reflekser svekket, slik at man må være ekstra varsom ved ned- legging av sonden. Det finnes imidlertid også flere beskrivelser av pasienter uten strålebehandlet kreftsykdom, noen med trakeostomitube og orale tuber med oppblåst mansjett, som har fått lagt ned tynn ernæringssonde ut gjennom pleura uten symptomer (1), for så å få en alvorlig pneumothorax i det ernæringssonden dras tilbake. Dette skjedde også hos vår pasient. Pleuradrenberedskap anbefales derfor før ernæringssonden trekkes ut (1).

Pasienten har gitt samtykke til at artikkelen blir publisert.

\section{Gunnbjørg Tysvær}

g.tysvaer@gmail.com

$\emptyset$ re-nese-hals /Kjevekirurgisk avdeling

Nordlandssykehuset Bodø

\section{Erik Waage Nielsen}

Akuttmedisinsk avdeling

Nordlandssykehuset Bodø

og

Profesjonshøgskolen

Universitetet i Nordland

og

Institutt for Klinisk medisin

Universitet i Tromsø
Gunnbjørg Tysvær (f. 1966) er overlege og spesialist i øre-nese-halssykdommer.

Forfatter har fylt ut ICMJE-skjemaet og oppgir ingen interessekonflikter.

Erik Waage Nielsen (f. 1956) er professor, overlege og spesialist $i$ anestesiologi.

Forfatter har fylt ut ICMJE-skjemaet og oppgir ingen interessekonflikter.

\section{Litteratur}

1. Freeberg SY, Carrigan TP, Culver DA et al. Case series: tension pneumothorax complicating narrow-bore enteral feeding tube placement. $\mathrm{J}$ Intensive Care Med 2010; 25: 281-5.

Mottatt 21.9. 2012, første revisjon innsendt 12.11. 2012. godkjent 15.11. 2012. Medisinsk redaktør Merete Kile Holtermann. 